\title{
COLLOQUIUM 5
}

\section{ATTEMPTING THE POLITICAL ART}

\section{CHRISTOPHER LONG}

\begin{abstract}
The main thesis of this essay is that the practice of Socratic political speaking and the practice of Platonic political writing are intimately interconnected but distinct. To develop this position, the essay focuses on the famous passage from the Gorgias in which Socrates claims to be one of the few Athenians who attempt the political art truly and goes on to articulate the nature of his political practice as a way of speaking toward the best (521d6-e2). It then traces the ways Socrates attempts to use words to turn Gorgias, Polus, and Callicles toward the best in the course of the dialogue. What emerges is a picture of a philosophical friendship between Gorgias and Socrates rooted in a common concern for justice. Yet, Socrates' success with Gorgias is overshadowed by his failure to convince Polus or Callicles to allow a concern for truth, justice, and the good to animate the course of their lives. Even so, the political practice of Platonic writing is shown in the essay to be designed to awaken in us, the readers, precisely such a concern to live a life in which words are spoken in ways that uncover the truth and are directed toward the best.
\end{abstract}

"For it is not possible, or not easy, to change by words things that have from long ago taken hold in people's character."

Aristotle, Nicomachean Ethics, X.9, 1179b17-8

In a burst of thumotic energy that marks a moment of truth at the center of Plato's Gorgias, Callicles discloses the transformative power of the practice of Socratic philosophy. The words of Socrates move him to it; for in his responses to Polus, Socrates had articulated a radical understanding of human life in which "an unjust deed must not be hidden, but rather brought out into the open in order that one might give justice and become healthy." This provoked Callicles to ask Chaerephon if Socrates is serious or just playing around. And when Chaerephon invites Callicles to ask Socrates himself, Callicles puts words to an unsettling truth: ". . . if you are serious, and if the things you say happen to be true [ $\dot{\alpha} \lambda \eta \theta \tilde{\eta}]$, would not our life as

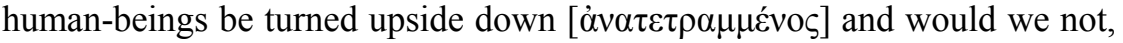
as it seems, be doing all things opposite to what it is necessary to do?"2 Callicles here recognizes that the things Socrates says, if true, have the power to transform our common life as human-beings by requiring us to act differ-

\footnotetext{
${ }^{1}$ Plato, Platonis Opera (Oxford: Oxford University Press, 1903), vol. III, 480c3-5.

${ }^{2}$ Gorgias 481c1-4.
} 
ently. ${ }^{3}$ And even if throughout the dialogue Callicles shows himself to be incapable of putting words to things in ways that bring justice into the open, here, provoked by Socrates, Callicles is moved to speak a truth that uncovers the political nature of Socratic philosophy.

Although Callicles unwittingly articulates the deep political implications of the things Socrates says, he goes on to dismiss the practice of Socratic philosophy as "ridiculous, unmanly, and something that deserves a beating." In language borrowed from Euripides' Antiope, Callicles urges Socrates to " "practice the beautiful music of affairs $[\pi \rho \alpha \gamma \mu \alpha \dot{\tau} \omega \nu]$ ' and practice such that 'you will seem sensible and leave these clever subtleties to others." "' Callicles' attempts to delineate a strict distinction between a philosophical life spent "whispering $[\psi 1 \theta \rho i ́ \zeta o v \alpha \tau \alpha]$ in corners" and a political life spent "giving voice $[\varphi \theta \dot{\varepsilon} \gamma \xi \xi \alpha \theta \alpha 1]$ to that which is free and great and opportune" leads Socrates finally to put the political practice at the heart of his philosophical life into words. ${ }^{6}$ This is what he says:

I think that with few Athenians, so as not to say the only one, I attempt the po-

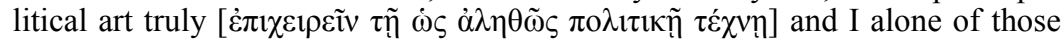

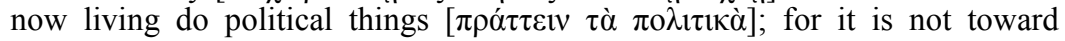

${ }^{3}$ Irwin is certainly correct to recognize here that "Callicles realizes the importance of Socrates' claims." However, he goes on to emphasize only one side of the important truth to which Callicles gives voice: "Probably Callicles means that Socrates' conclusions show that people's lives are upside down . . ., not that his conclusions will turn their lives upside down ..." See Irwin 1979, 169. Yet, it is likely that the passage implies that the truth of the things Socrates says is capable both of showing that people's lives are upside down and of turning those upside down lives right side up again by orienting them toward the question of justice. There are diagnostic and therapeutic dimensions to the truths Socrates speaks.

${ }^{4}$ Gorg. 485c1-2.

${ }^{5}$ Gorg. 486c4-6. In the Antiope Euripides is said to have depicted two brothers, Zethus, a herdsman, and Amphion, a musician, engaged in a discussion of their two ways of life. According to Dodds, Euripides used this as an opportunity to extend the question to a general comparison between the practical and the contemplative life. See Dodds 1959, 275-6. Pickard-Cambridge offers a reconstruction of the plot in which Zethus berates his brother, Amphion, for being useless and effeminate as Amphion defends the pursuit of music and philosophy. The discussion seems to have concluded with Amphion acquiescing to go hunting with Zethus. See Picard-Cambridge 1933, 107-8. For another reconstruction of the plot and specifically of the section Callicles seems to draw upon, see Wecklein 1924, 58-62.

${ }^{6}$ Gorg. 485d9-e2. Note here that Callicles articulates these two ways of life in terms of different ways of speaking: the philosopher "whispers," the politician "gives voice." The Greek, $\varphi \theta \varepsilon \dot{\gamma} \xi \alpha \sigma \theta \alpha$, points to the permeable boundary between the uttering of mere sounds and the sort of voicing capable of carrying meaning - it is situated at the border between the utterances of human and non-human animals. As will be heard, Socrates articulates his own

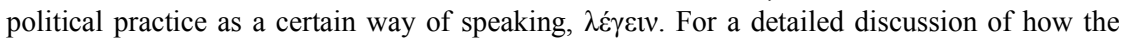
boundary between human and non-human voicing is blurred in ancient Greek thinking, see Long 2011, 72-115. 
[ $\pi \rho$ ò $\varsigma$ gratification that I speak the speeches I speak on each occasion, but to-

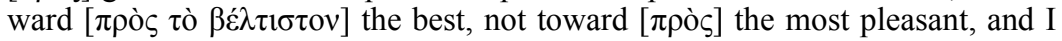
am not willing to do the things you recommend, "those clever subtleties," I will not have anything to say in the court of justice. ${ }^{7}$

The words Plato puts into the mouth of Socrates here eloquently articulate the political nature of the practice of Socratic philosophy. But if we attend both to what Socrates says to Callicles in this dialogical context and to how Plato has him say it, we will learn not only that the political practice of Socratic philosophy involves a certain way of speaking, but also that Platonic writing itself performs a certain kind of politics. If discerning the practice of Socratic politics requires attending carefully to the ways Socrates speaks "toward the best," discerning the poetics of Platonic politics requires an ability to hear how the things he has his characters say in the dialogue are themselves crafted to turn the attuned reader "toward the best." Listening thus in a double register not only to what Socrates says to Callicles in this dramatic context, but also to how Plato has him say it, will uncover the complex and intimate interconnection between the politics of Platonic writing and that of Socratic speaking. To anticipate: Platonic writing tries to do with us what Socratic saying tries to do with those he encounters. The passage in which Socrates is made to articulate the nature of his political practice thus speaks on two levels. On what might be called the apophantic level, the written text shows the philosophical life to be integrated with the political life; on the dialogical level, the things Socrates says to Callicles challenge the traditional manner in which Athenian politics is practiced. An apophantic and dialogical double reading of this passage opens the possibility of a double reading of the Gorgias as at once depicting the practice of Socratic politics and performing the politics of Platonic writing.

\section{Doing Things with Words}

In one sense, it is impossible to maintain a strict distinction between what Socrates says and how Plato has him say it, for the Socrates we encounter in the Platonic dialogues is, as Plato himself puts it, a Socrates "become beautiful and new." 8 Yet in the passage under consideration, there are three

\footnotetext{
${ }^{7}$ Gorg. 521d6-e2.

8 Plato and John Burnet, Platonis Opera (New York: Oxford University Press, 1907), vol. $\mathrm{V}, 314 \mathrm{c} 4-5$. There are, obviously, other sources on which to draw for a picture of the historical Socrates. But that endeavor, undertaken by many able scholars, is beside the point made here which remains concerned exclusively with the difference between Plato the philosopherdramatist and the figure of Socrates who appears in Plato's philosophical dialogues. For a
} 
repetitions that suggest the manner in which Platonic writing attempts to turn the reader's attention toward the question of the good and heighten the reader's awareness of the relationship between the way things are said and a concern for the best. The first and perhaps most striking instance of repetition is heard in the polyptoton of the Greek word for speaking itself, $\lambda \dot{\varepsilon} \gamma \varepsilon t v$, when Socrates says "I speak the speeches I speak on each occasion $(\lambda \dot{\varepsilon} \gamma \omega \mathrm{v}$

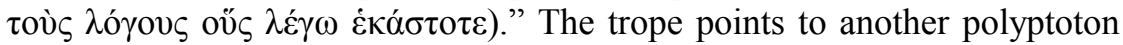
toward the very beginning of the Gorgias, in which Polus responds to Chaerephon's questions concerning who Gorgias is by launching into a display of words in which he repeats iterations of the Greek word for experience, $\dot{\varepsilon} \mu \pi \varepsilon i \rho i ́ \alpha:$ "Many are the arts among human-beings, Chaerephon, that have been discovered experientially from experience, for experience makes the course of life pass along the path of art, and inexperience along the path of luck." In speaking of the art of which Gorgias partakes, Polus shows himself to have a certain kind of rhetorical knack, for he has the hang of how to play with sounds in appealing ways. Thus, Plato's decision to put such a rhetorical "jingle" into the mouth of Socrates as he articulates his political art may be taken as an attempt to highlight the difference between how Socrates attempts to do political things with words and how political speech is so often designed to gratify an audience.

Indeed, the practice of Socratic politics is characterized as a way of speaking oriented toward the best as opposed to the merely pleasant. This too is emphasized in writing by the appearance of a second trope of repetition as Socrates is made to speak the preposition $\pi \rho$ ò $\varsigma$, or 'toward,' three times. Socrates insists that he speaks "not toward gratification . . . but toward the best, not toward the most pleasant." 10 As Dodds points out, this is an " $a b a$ construction." 11 The anaphora gestures to the erotic dimension of political speaking and emphasizes the importance of that toward which one's speech is directed. It thus points back to Socrates' response to that passage with which we began, when Callicles reinserted himself into the middle of the dialogue. There, Socrates suggests that he and Callicles share a common experience, for "we are two lovers, each in love with two things." 12 The distinction between the things they each love, in fact, parses along the line between what is most pleasant and what is best that is estab-

compelling recent attempt to discern the historical circumstances around the trial and execution of the historical Socrates, see Brickhouse and Smith 2002.

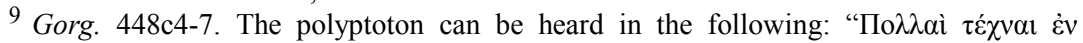

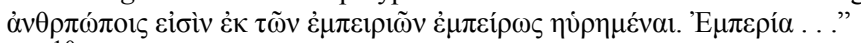

${ }^{10}$ Gorg. $521 \mathrm{~d} 8$-e1.

${ }^{11}$ Dodds 1959, 369.

12 Gorg. $481 \mathrm{~d} 3$. 
lished by the repetition of the $\pi \rho$ ò $\varsigma$ in the passage under consideration. Socrates is in love with Alcibiades and philosophy, Callicles with Demos, the son of Pyrilampes, and the Athenian demos. ${ }^{13}$ If Socrates' two beloveds pull him often in opposite directions, the one toward pleasure, the other toward the best, Callicles is pulled by both of those he loves toward gratification and the maximization of pleasure. If the words Callicles speaks in speaking to Socrates bespeak his erotic attraction toward what is most pleasant, the words Plato writes and the ways they are written call attention to the political implications of allowing our words to be animated by an erotic attraction toward gratification.

The third repetition Plato puts into the mouth of Socrates here is the reiteration of words Callicles had spoken earlier as he quoted from a passage in Euripides' Antiope in which Zethus enjoins his brother Amphion to give up the effeminate musical life and turn his attention to more practical things. Thus, Plato makes Socrates refuse Callicles' advice to give up "those fancy subtleties" by repeating the words themselves. This refusal in those words invites us to consider the degree to which Socrates' own political practice subverts the traditional way of understanding the distinction between the philosophical and the political life as separate and opposed. Taken together, these three instances of written tropes of rhetorical repetition point us to a politics capable of doing things with words when they are rooted in and directed toward an erotic concern for the best. The repetitions themselves require us, as readers, to consider the extent to which philosophy, be it spoken or written, cannot be divorced from politics; for in drawing our attention to the relationship between the words we articulate and the question of the best, the words written by Plato invite us to reflect upon the manner in which we use words to do things in our lives with one another.

But Platonic writing derives its real political power from the manner in which it depicts the figure of Socrates putting politics into practice in a specific way. Let us attend, then, to what Socrates says his political practice involves in the passage we have been considering. It begins in a quintessentially Socratic manner by presenting a most serious point in playful language. "I think that with few Athenians, so as not to say the only one, I attempt the political art truly and I alone of those now living do political things. . . ."14 As a personal supposition rather than a simple assertion, the arrogance of the claim is tempered even as its effect as a critique of Atheni-

${ }^{13}$ Demos, the son of Pyrilampes, was called "beautiful" by Aristophanes and "stupid" by Eupolis. See Nails 2002, 124. This, of course, does not speak well of Callicles' erotic judgment, if judgment there be in such cases.

14 Gorg. 521d6-8. 
an politics is heightened. Socrates embraces the practice of politics here in a way that superficially seems to contradict a statement he had made earlier to Polus in which he claimed "I am not of the politicians." 15 Yet here, a different sort of politics comes to language; for its way of doing is assaying-

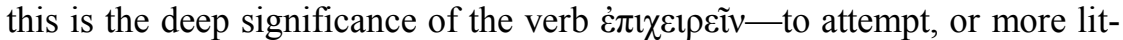
erally, to try one's hand at something. ${ }^{16}$ And he goes on to lend determination to what it means to "attempt the political art truly" when he suggests that it involves a way of speaking oriented not toward gratification, but toward the best.

What is thus heard in this passage is an implicit critique of a certain way of political speaking, a recognition that the doing of political things involves a specific ability to do things with words. Socrates lends determina-

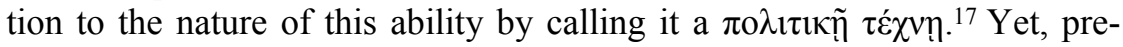
cisely what Socrates means by emphasizing that his political ability is itself a $\tau \dot{\varepsilon} \chi v \eta$ can only be discerned by attending to the manner in which he appeals to $\tau \dot{\varepsilon} \chi v \eta$ in the course of the dialogue, where, as will be heard, it names a practice that is held to account on "each occasion" by an erotic relationship "toward the best." Already in the passage under consideration Socrates emphasizes the manner in which he attempts the political art; for he says he attempts the political art truly- $\dot{\omega} \dot{\alpha} \lambda \eta \theta \tilde{\omega} \varsigma$. The adverbial clause is designed to differentiate the practice of Socratic politics from the standard practice of Athenian politics. But the qualification is more than a mere differentiation; for the practice of Socratic politics is the attempt to speak truth, and in so speaking, to reveal the nature of things and to uncover the possibilities of community that emerge when words are oriented by a concern for what is best.

From its earliest beginnings in ancient Greek epic poetry, $\dot{\alpha} \lambda \hat{\eta} \theta \varepsilon 1 \alpha$ has always been intimately linked to the domain of saying. ${ }^{18}$ In Homer, the term appears in everyday contexts in which someone asks for a response that uncovers the reality of things..$^{19}$ The tradition that connects truth with ways

15 Gorg. $473 \mathrm{e} 6$.

${ }^{16}$ Irwin is right to emphasize this dimension of Socrates' claim: "Socrates does not say

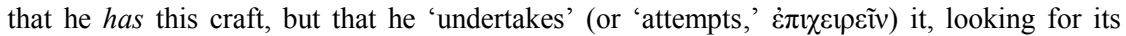
principles; and so this remark need not conflict with his previous disavowal of knowledge." See Irwin 1979, 240.

${ }^{17} \mathrm{He}$ seems to emphasize the status of the activity as a $\tau \dot{\varepsilon} \chi v \eta$ insofar as calling it simply a

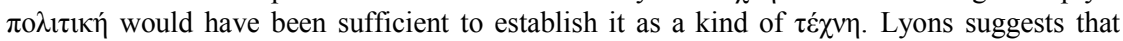
"the form in -ıкท may be used indifferently with or without $\tau \varepsilon \dot{\chi} \chi v \eta$ and in either case it will be picked up by $\tau \dot{\varepsilon} \chi v \eta$ with equal readiness" (Lyons 1963, 143).

18 Boeder 1959, 94.

${ }^{19}$ For a detailed discussion of the history of truth in ancient Greek culture and philosophy, see Long 2010, 21-48. 
of speaking that are at once directed toward determinate individuals in concrete social-political contexts and concerned to uncover the nature of things is heard throughout the Gorgias. This is clear already in dialogue's first iteration of $\dot{\alpha} \lambda \eta \dot{\eta} \theta \varepsilon \alpha$ when Chaerephon poses the question to Gorgias: "is Callicles here speaking the truth [ $\left.\dot{\alpha} \lambda \eta \theta \tilde{\eta} \lambda \varepsilon^{\prime} \gamma \varepsilon 1\right]$, that you claim to answer whatever anyone asks you?" To this, Gorgias responds: A $A \lambda \eta \theta \tilde{\eta}$ ("it is true"). ${ }^{20}$ This is, indeed, the first word Plato puts into the mouth of Gorgias, suggesting already that the question concerning the speaking of truth will be a matter of central importance to the discussion. This suggestion is reinforced by the adverbial qualification Socrates inserts into the center of his articulation of the political art he attempts. Perhaps, then, deeper insight into both the practice of Socratic politics and the politics of Platonic writing will be gained by following an itinerary through the Gorgias in which the

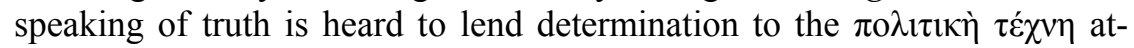
tempted by Socrates and Plato both. Such an itinerary will also lend insight into the extent to which the true political art has the capacity, as Callicles had recognized, to turn our common life as human beings upside down. For the terms championed by each interlocutor with whom Socrates speaks in the Gorgias - rhetoric over dialogue, power over truth, politics over philosophy - are shown to be reversed in the course of the dialogue as Socrates articulates an understanding of $\tau \dot{\varepsilon} \chi \vee \eta$ as erotically oriented toward the best. ${ }^{21}$ And because the model for this $\tau \dot{\varepsilon} \chi v \eta$ is doctoring, it is perhaps appropriate to understand this reversal in more organic language, for what the Gorgias shows is that rhetoric is rooted in dialogue, power in truth and politics in the practice of philosophy.

\section{Gorgias: Articulating a True Rhetoric}

What begins as a question "concerning the power that belongs to the man's art, and what it is he proclaims and teaches" quickly becomes an instruction to ask: "who is he?"22 The transition is quick: Socrates says he is interested in learning about the $\tau \dot{\varepsilon} \chi v \eta$ Gorgias claims to practice and teach, and specif-

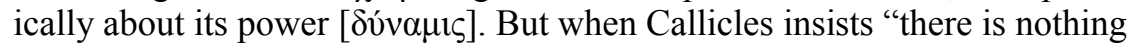
like asking the man himself," Socrates implicitly refuses, directing Chaero-

${ }^{20}$ Gorg. 447d7-448a1.

${ }^{21}$ Rocco has suggested that this list of dichotomies "remain the essentially contested terms in the agonistic economy of Plato's Gorgias." See Rocco 1996, 363. Although the Gorgias remains itself agonistic to the end, there is within the agonistic context, a sort of friendship that emerges between Gorgias and Socrates.

22 Gorg. 447c-d. 
phon to ask Gorgias who he is. The power of the art Gorgias claims to teach seems, thus, to be intimately related to the sort of person he is and the sorts of people he influences. Plato amplifies the importance of these connections by having the direct conversation between Gorgias and Socrates mediated by a display of ineptitude by their associates, each of whom shows himself to be incapable of dialogue. ${ }^{23}$ Once Gorgias does in fact respond directly to Socrates, Socrates introduces the central tension at stake in his initial discussion with Gorgias, the difference between rhetoric and dialogue. ${ }^{24}$ These initial encounters, then, suggest that the power of the $\tau \dot{\varepsilon} \chi \nu \eta$ one practices is intimately bound up with the sort of person one is and that both the art one proclaims and teaches and the life one lives are rooted fundamentally in the way one does things with words.

The conversation between Gorgias and Socrates is, in fact, marked by a concern not merely to identify the power of the art Gorgias claims to teach, but more importantly, by a concern to turn Gorgias toward the question of justice so as to allow this question to inform and guide his art of speaking. The dialogue between them is itself marked by a certain concern for justice that is heard in those moments of candor when Socrates reveals to Gorgias who he is and why he speaks the way he does. It would, indeed, be difficult to identify an interlocutor in the Platonic dialogues with whom Socrates uncovers more about his own ways of speaking than he does with Gorgias in the Gorgias. ${ }^{25}$ Despite the generally antagonistic atmosphere, a genuine friendship seems to emerge between Socrates and Gorgias, a friendship nourished, it seems, by mutual respect, a certain playfulness and, indeed, a strong commitment to candor. ${ }^{26}$ Thus, although Socrates explicitly raises

${ }^{23}$ Interestingly, Socrates is shown to instruct Chaerephon in the dialogue as to precisely how to speak, Gorgias's interaction with Polus is merely to move him out of the way so that the $\lambda$ ó $\gamma$ oৎ might continue-Socrates is the only one in the dialogue shown actually attempting to teach.

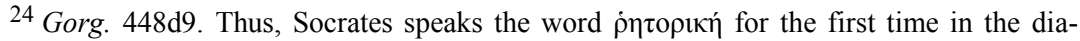
logue, juxtaposing it explicitly with $\delta 1 \alpha \lambda \varepsilon \dot{\varepsilon} \varepsilon \sigma \theta \alpha$. This, of course, is a deepening of the initial

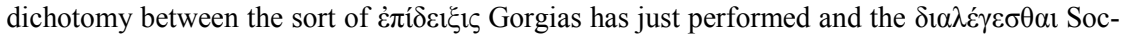
rates seeks (447b6-c4).

${ }^{25}$ Something analogous happens between Socrates and Protagoras in the Protagoras when Socrates insists that the dialogue proceed in short speeches because he wants to examine the logos well, though, as he suggests, this might also involve an examination of the one's asking and answering. See, Prot. 333c7-9 and 331c-d. For a discussion of this, see Long 2011,374-5n29.

${ }^{26}$ Weiss calls attention to the respect that seems to emerge between Socrates and Gorgias. See Weiss 2003, 200. Teloh sees Gorgias as "arrogant," but recognizes that Gorgias seems to "take a genuine interest in the remainder of the conversation," even facilitating it at times. See Teloh 2007, 64. Fussi too recognizes the importance of the ongoing presence of Gorgias in the dialogue, but she also emphasizes that Gorgias, both as a stranger in Athens and as an 
the question of frank speaking, or $\pi \alpha \rho \rho \eta \sigma i \alpha$, only in the context of his discussion with Callicles, he puts $\pi \alpha \rho \rho \eta \sigma i \alpha$ into practice with Gorgias, uncovering the true motivations behind his own ways of speaking. ${ }^{27}$ In speaking frankly about his own method, in attempting to articulate the sort of person he is, Socrates uncovers a truth about his practice of philosophy that seems to have been compelling enough to Gorgias that he remains an active participant in the dialogue even after he has supposedly been shamed into defeat by Socrates. If, however, the political power of the words Socrates speaks to Gorgias is illustrated by their capacity to move Gorgias toward the best by turning his attention to the question of justice, Gorgias's continuing participation at decisive moments in the dialogue shows the degree to which the poetics of Platonic politics is concerned to demonstrate the power of a rhetoric rooted in the pursuit of truth. ${ }^{28}$ By tracing those moments of candor

orator selling his rhetoric, cannot be as candid as Socrates. See Fussi 2001, 125 and 144. The element of play can be heard at 449d5-7 when Socrates and Gorgias agree with Gorgias is doing an admirable job giving short answers.

${ }^{27}$ Monoson points to the six appearances of the term ' $\pi \alpha \rho \rho \eta \sigma i ́ \alpha$ ' in the dialogue $-487 \mathrm{a} 3$, 487b1, 47d5, 491e7-8, 492d2, 521a6 - all of which occur in the discussion between Socrates and Callicles. See Monoson 2000, 162. Given the extent to which $\pi \alpha \rho \rho \eta \sigma i \alpha$ was one of the core values affirmed and cultivated by the Athenian citizenry, it is no surprise that the issue emerges explicitly as a theme in the context of a discussion between two Athenians. Socrates himself suggests that $\pi \alpha \rho \rho \eta \sigma i ́ \alpha$ would have been cultivated in Callicles, him "having been educated sufficiently, at least as many Athenians would assert ..." (487b6-7). Socrates here implies his own disagreement with what many Athenians consider to be a good education. That Callicles shows himself to be incapable of frank speech further reinforces the irony of Socrates' praise of Callicles for $\pi \alpha \rho \rho \eta \sigma i \alpha$. For a discussion of the extent to which $\pi \alpha \rho \rho \eta \sigma i ́ \alpha$ was a deeply held value of the Athenian democracy, see Saxonhouse 2006, 85-126. The question of whether Socrates is being frank when, at Gorg. 486e6-488b1, he calls Callicles a touchstone of the adequacy of the truth concerning the things his soul believes is a matter of some debate. There Socrates suggests Callicles has knowledge, goodwill and frankness, which makes him an ideal interlocutor for Socrates. The case against taking Socrates at his word with regard to knowledge and goodwill seems fairly straightforward as Callicles shows himself in the dialogue neither to possess knowledge nor to have good will toward Socrates. McKim makes the compelling argument that Socrates "is being just as ironical about frankness as he is about knowledge and goodwill" (McKim 1988, 40). Teloh agrees that Socrates' praise of Callicles here is ironic (Teloh 2007, 68). Dodds offers a different view, seeing Callicles as caring sincerely for Socrates and hearing Socrates' praise of Callicles' frankness as genuine. See Dodds 1959, 14 and 263. Even if we take Socrates as being ironic about Callicles' specific characteristics, it is nevertheless possible to take Socrates seriously when he insists that their agreement would be "the complete truth." See, Gorg. 487e7.

${ }^{28}$ Stauffer has emphasized that Gorgias's continuing interventions in the dialogue are signs that "Socrates has succeeded in capturing his interest" and even that Gorgias has learned the importance of turning toward justice. See Stauffer 2006, 120-1. Kastely argues convincingly that Gorgias is more than a mere foil for Socrates, but is, in fact, an example of a rhetorician who understands his art as "existing for the benefit of the community." See Kastely 1991, 99-100. Plato's writing reinforces the importance of this commitment to community by 
in which Socrates articulates why he speaks to Gorgias the way he does, we will begin to discern the deep connection in speaking truth and practicing the political art. By attending to the continuing presence of Gorgias in the dialogue, we will hear something of the true political art of Platonic writing.

\section{Speaking Truth with Gorgias}

There are two moments of candor in Socrates' dialogue with Gorgias worthy of attention in this context. The first is heard after Gorgias is led to agree that rhetoric is an art that, as Socrates says, "brings about and accomplishes everything by means of words." ${ }^{29}$ But when asked about the nature of these things rhetoric does with words, Gorgias insists that they are "the greatest of human concerns, Socrates, and the best." ${ }^{30}$ Socrates then seeks clarity on precisely what these greatest and best things, in fact, are, although after they agree that "rhetoric is a producer of persuasion," Socrates admits that he has a suspicion about the things with which rhetoric is concerned.$^{31}$ Here, however, Socrates inserts into the discussion an account of the sort of person he is as a way of revealing to Gorgias the reason why he continues to ask him about the things with which rhetoric is concerned rather than asserting his own suspicions straight away. "Listen, Gorgias," Socrates begins and in so beginning calls attention to the need to pay attention, "know well that I am one of those, as I persuade myself, who, if someone engages with another in dialogue, wants to know the very thing concerning which the $\lambda$ ó $\gamma o \varsigma$ exists. And I consider you to be such a person too." 32 The gesture to persuasion as what offers Socrates insight into the sort person he is, at once amplifies the connection between Gorgias and Socrates - for here they are said to be the same - and suggests that there is an element of suasion endemic to dialogue itself. Indeed, the desire to know the very thing about which they speak seems to animate their engagement with one another - or so Socrates hopes to persuade Gorgias. By revealing the sort of person he is, Socrates attempts to cultivate in Gorgias a shared desire to know the thing itself. Thus, he continues by emphasizing what

having Gorgias intervene at moments when the community of dialogue threatens to break down.

${ }^{29}$ Gorg. $451 \mathrm{~d} 2-3$.

${ }^{30}$ Gorg. $451 \mathrm{~d} 7-8$.

31 Gorg. 453a2-c1.

32 Gorg. 453a8-b3. The anacoluthon makes the passage difficult to get into English with sufficient nuance to capture the urgent manner in which Socrates reveals something decisive about himself in order to establish a deeper connection with Gorgias. Despite this difficulty, Dodds says this is "a natural and fairly common type of anacoluthon." See Dodds 1959, 203. 
motivates his desire to proceed by questioning rather than asserting his own suspicions: "It is not for your sake, but for the sake of the $\lambda$ ó $\gamma$ os, in order that it might proceed forward in a way that makes what we are saying as

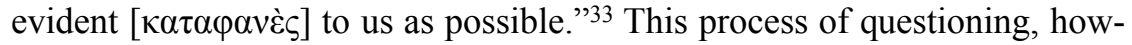
ever, cannot be construed to mean that Socrates is unconcerned with Gorgias as a person. To the contrary, that Gorgias is someone who wants to uncover the very thing about which they are speaking is the condition under which their dialogue proceeds. Strangely enough, however, Socrates conceals his suspicions momentarily in order to try to move Gorgias to become the sort of person Socrates says he considers him to be, namely, one who himself "wants to know the very thing concerning which their $\lambda$ ó $\gamma$ os exists."

Once Socrates leads Gorgias to articulate what Socrates had himself suspected-that rhetoric concerns the sort of persuasion that goes on in law courts and in crowds - there appears another moment of candor, prompted again by the hyperbolic praise Gorgias has for the power of rhetoric. "It holds all powers together within itself," says Gorgias as he launches into the famous story of how his brother, the doctor, is powerless without rhetoric if he is unable to persuade his patient to drink his medicine or submit to burning. ${ }^{34}$ In this speech, however, Gorgias also evokes the example of the skilled boxer who must learn how to use the skill "in a just manner." ${ }^{35}$ By introducing the question of the just use of power here, Gorgias shows himself to be, like Socrates, concerned with justice, which, it seems, is the very thing concerning which their speech exists.

Recognizing the emergence of a shared erotic interest in the just, Socrates seeks to deepen the level of their connection. He begins by appealing to an experience he and Gorgias must share in discussions such as these when people allow the "desire to win" to distort their inquiry into "that which lies there before them in their speech." 36 He goes on to say: "I fear in my dialogue with you, that you might take me to be speaking from a desire to win against you rather than for the matter at hand [ $\tau$ ò $\pi \rho \tilde{\alpha} \gamma \mu \alpha]$ to become evi-

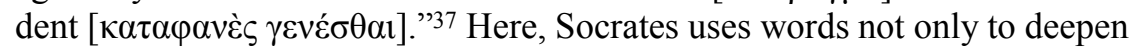
his relationship with Gorgias by uncovering what motivates the things he says, but also to direct their shared attention toward the attempt to use words in such a way that the nature of the matter at hand becomes evident. Thus, Socrates speaks truth as $\dot{\alpha} \lambda \hat{\eta} \theta \varepsilon \iota \alpha$ with Gorgias in a rich double sense,

\footnotetext{
33 Gorg. 453c2-4. Cf., Protagoras, 331c-d, 333c7-9 and n25, above.

${ }^{34}$ Gorg. 456a7-457c3.

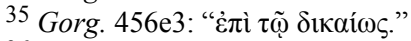

36 Gorg. 457c4-d5.

37 Gorg. 457e3-5.
} 
for his words uncover a common bond between them, affirming their shared concern for justice, even as they also reveal the degree to which this shared matter of concern will only become evident if they are able to speak together in ways that articulate its nature. Speaking truth is heard here to be capable at once of opening a space of community and of uncovering the nature of things. For this reason, Socrates seeks to root his relationship with Gorgias in a shared loyalty toward the truth, suggesting that they ought not to continue if Gorgias is not the same sort of person he is. Socrates puts it this way: "And what sort of person am I? The sort for whom it is a pleasure to be refuted, if I say something that is not true, but who is pleased to refute if someone should say something that is not true, and no more displeased to be refuted than to refute." ${ }^{38}$ Gorgias responds by affirming that he himself is just such a person, and in the course of the rest of the dialogue, he shows himself increasingly to be one who uses words to nourish the community of dialogue and to make what they are saying as evident as possible.

These two moments of truth cultivate in Gorgias a desire for truth that becomes manifest the moment he recognizes that if a person comes to him not knowing what is just and unjust, good and bad, beautiful and shameful, these things will need to be learned as part of the art of rhetoric itself. Gorgias is moved to this recognition by Socrates' attempts to speak the truth to and with him. Thus, his dialogue with Gorgias must be heard as politics in practice, for Socrates speaks toward the best: he uses words to turn Gorgias's attention toward the question of the just in such a way that it is felt to inform not only what he teaches, but who he is. The art of rhetoric is here shown to be rooted in true dialogue. If, however, the power of Socratic politics is felt in the dialogue of truth that emerges between Gorgias and Socrates, the nature of the relationship between truth and power comes explicitly to language in the discussion with Polus, but only because Gorgias is willing to use words of his own to move the discussion in that direction.

\section{Polus: Turning Toward the Best}

Polus breaks into the dialogue between Socrates and Gorgias in order to insist that Gorgias was shamed [n் $\chi \chi 0 v \theta \eta]$ into conceding something he himself did not believe, for, as Polus puts it: "who do you think would utterly deny either that he knew what is just or that he could teach it to oth-

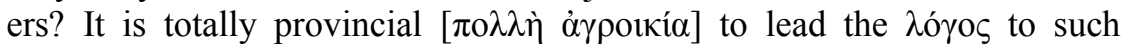

\footnotetext{
38 Gorg. 458a2-5.
} 
things." ${ }^{39}$ For all his bravado, Polus speaks the truth here in two respects. First, even if he rejects its plausibility, Polus beautifully articulates precisely what Socrates says about himself; for Socrates is just such a one to deny that he knows the just things, and that he teaches them to others. ${ }^{40}$ Second, even if he finds what Socrates does provincial, Polus speaks well when he says that Socrates "leads the $\lambda$ ó $\zeta_{0} \varsigma^{\circ}$ in a specific direction; for Socrates leads the $\lambda$ ó $\gamma \circ \varsigma$ precisely toward just things. Indeed, the power of speaking the truth we have been tracing in the dialogue lies in its ability to move others toward justice by means of words; but this involves cultivating in them a knowledge of their own ignorance of just things, and a desire to know them. The interruption of Polus threatens to derail the $\lambda$ ó $\gamma \circ \varsigma$ from its path of truth.

Thus, when Polus finds himself at a loss about what Socrates is saying, Socrates attempts to return the $\lambda$ ó $\gamma$ os to the truth. "Perhaps speaking the

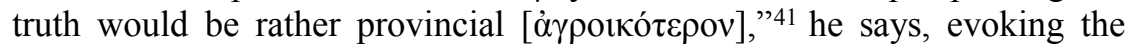
original insult by which Polus had interrupted his dialogue with Gorgias. Socrates then goes on to suggest that he hesitates, however, to speak the truth lest Gorgias imagines that he is satirizing his business. ${ }^{42}$ Still, Socrates

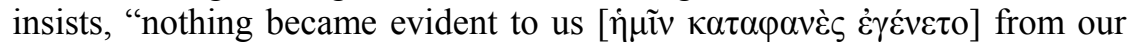
recent $\lambda$ ó $\gamma$ o $\varsigma$ about what he thinks it is." 43 Here again, the connection between speaking the truth and allowing the matter of their dialogue to "become evident" is emphasized. Now for a third time, Socrates has sought to redirect the conversation toward the question of justice and the best by appealing to the importance of allowing the matter at hand to become

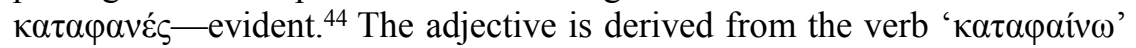
which means "to declare" or to make clear by words. ${ }^{45}$ Each time it appears

${ }^{39}$ Gorg. 461c2-3. The translation of "provincial" here does not, perhaps, capture the rudeness of Polus's insult. Arieti and Barrus translate it as "redneck" in order to underscore

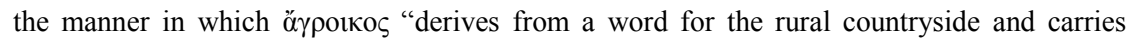
connotations of roughness and boorishness." See Arieti and Barrus 2007, 49n39.

${ }^{40}$ Regarding knowledge, see Apology 21d-e; regarding never being anyone's teacher, see Ap. 33a-b.

${ }^{41}$ Gorg. $462 \mathrm{e} 6$.

42 Arieti and Barrus are right to suggest that the echo of Polus's use of the term ö $\gamma$ potкo indicates that Socrates is being sarcastic. See Arieti and Barrus 2007, 51n42. The sarcasm is directed at Polus and designed to reorient the encounter between them toward the truth. Socrates' professed concern for the feelings of Gorgias is perhaps more genuine, for Socrates has shown himself, like a good host, to be concerned with the feelings of his guest. Together, the repetition of Polus's original insult and the gesture of guest friendship toward Gorgias show Socrates to be rather urbane.

43 Gorg. 463a1-2.

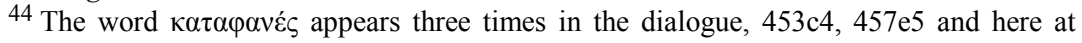
$463 \mathrm{a} 2$.

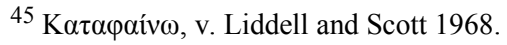


in the dialogue, Socrates is attempting to turn the discussion toward the question of justice and the best and to avoid the impression that the things being said are intended to put Gorgias to shame. And each time it is spoken, Gorgias responds by urging Socrates to continue, just as he does here, when he re-enters the dialogue, insisting that Socrates "speak, and have no shame on my account." 46

Socrates may thus be heard to practice a declarative politics in which words are used to allow the matter at hand to become evident and new communities of relation are opened by what is thus made clear. In this context, the attempt to make the nature of the power of rhetoric evident involves articulating an elaborate analogy between the care of the soul and that of the body in which two arts [ $\left.\tau \varepsilon_{\chi}^{\prime} v \alpha_{1}\right]$ concerning each are set against two experiences [ $\dot{\varepsilon} \mu \pi \varepsilon t \rho i \alpha 1]$ in order to reveal the degree to which the way Polus does things with words is perverted by an unhealthy conception of power. However, the difference between the reality of health and its appearance is established in dialogue, not with Polus, but with Gorgias, who affirms the distinction by telling Socrates: "you speak the truth." ${ }^{77}$ The truth Socrates speaks here both articulates the difference between the art and the experience of politics and uncovers two dimensions of what Socrates later calls his own political $\tau \dot{\varepsilon} \chi \vee \eta .^{48}$

The first difference Socrates articulates between the art and the experience of politics involves the end toward which it is directed. As arts, poli-

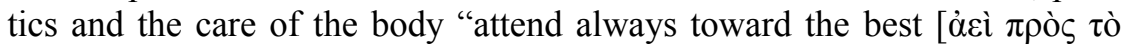
$\beta \varepsilon \dot{\lambda} \tau \tau \sigma \tau o v] . "{ }^{49}$ The words here anticipate those Socrates will use to describe his own practice of politics as a $\tau \dot{\varepsilon} \chi \nu \eta$, which involves saying things, as we

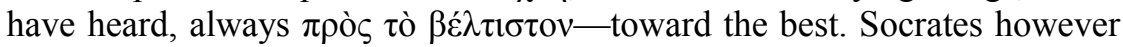
brings the significance of this formulation into focus by juxtaposing it explicitly with a way of speaking he characterizes as mere pandering. In so doing, Socrates directs his own attention to Polus rather than Gorgias. This is what he says:

I call this pandering and I say it is shameful, Polus-for this I am saying toward you - because it aims at pleasure without what is best. And I say it is not

${ }^{46}$ Gorg. $463 \mathrm{a} 5$.

47 Gorg. 464a5-6.

48 The analogy, elaborate and complex, begins at $464 \mathrm{~b} 2$, with Socrates calling them to "come along and, if I have the power, I will display for you more clearly what I am saying."

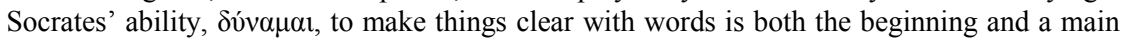
theme of the speech laying out the difference between the art of and the knack for politics. Kahn recognizes this speech as the beginning of "the positive exposition of this conception of politics" as a $\tau \varepsilon ́ \chi v \eta$ which is "spread throughout the dialogue." See Kahn 1983, 101.

${ }^{49}$ Gorg. $464 \mathrm{c} 4$. 


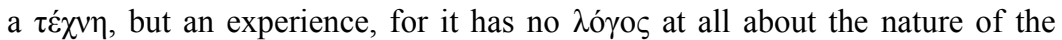
things it brings about or bears upon-whatever they may be; and thus, it has no

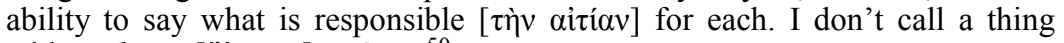

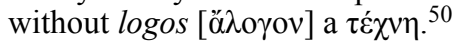

This passage has been taken to establish "rationality" as a condition for calling something an art. ${ }^{51}$ But that translation fails to capture the rich significance of the $\lambda$ ó $\gamma$ os Socrates seeks to clarify by putting into practice. For Socrates, a $\tau \dot{\varepsilon} \chi v \eta$ is able to give an account of the nature of the things it brings about and bears upon, an account Gorgias, Polus, and Callicles show themselves to be incapable of articulating. To be without $\lambda$ ó $\gamma$ o $\zeta$ is to be unable to say what is responsible for each of the things the art is undertaken to accomplish or affect. By explicitly directing his words to Polus as he establishes the difference between the art of politics and pandering, Socrates attempts not only to speak the truth about politics as a way of speaking toward the best, but also to use words to turn Polus toward the best by holding him accountable to the nature of the things he does with words.

This question of accountability bears upon the intimate connection between speaking the truth and power, a connection Polus is unable to recognize because his conception of power is perverted. For Polus, power is "the ability to do in the city whatever seems best for oneself." 52 Socrates responds to this understanding of power by introducing a distinction between "doing what one wants" and "doing what seems best" that forces Polus to attend to the question of the best and the deep connection humans have to it. ${ }^{53}$ In changing the way they speak about power, Socrates attempts to change the way they seek power through speaking. For Socrates, "doing

${ }^{50}$ Gorg. 464e2-465a6.

${ }^{51}$ Gould identifies three characteristics of a $\tau \dot{\varepsilon} \chi v \eta$, it should involve a "rational procedure" and have "comparative rarity and dependability." See Gould 1972, 34. Irwin argues that, because crafts are rational, teachable, and involve clearly delineated objective methods for settling questions, Socrates "has good reasons for thinking that real virtue . . . will be a craft. . .." (Irwin 1979, 73-5). Nussbaum has been highly critical of this view of $\tau \dot{\varepsilon} \chi v \eta$, because it lends itself to an instrumental view of ethical deliberation. See Nussbaum 1986, 97-8. This, however, is only one of the limitations of the view, for the deeper issue is that it reduces the rich complexity of the Greek $\lambda$ ó $\gamma o \zeta$ to only one of its meanings and imports a modern understanding of rationality into an ancient idea that is rooted in our deepest encounters with things. The far better approach is to determine the meaning of ö $\lambda$ oyov by attending to the way Socrates appeals to the $\lambda$ ó $\gamma o \zeta$ in relation to it. Roochnik, who agrees with Nussbaum against Irwin and Gould, approaches the question of $\tau \dot{\varepsilon} \chi v \eta$ in Plato much in the spirit of the present essay, by attending to how the term appears in the dialogues. See Roochnik 1996, 5.

52 Gorg. 469c5-6.

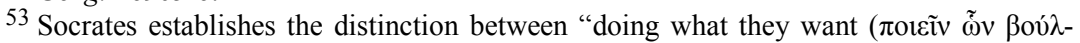

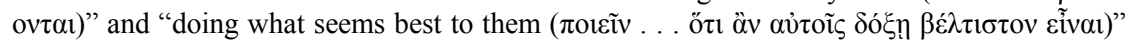
at $466 \mathrm{~d} 8-\mathrm{e} 2$. 
what one wants" is identified with just actions that are good for the community and thus for the individual, while "doing what seems best to one" is associated with the arbitrary freedom of the tyrant. Socrates insists that in making this distinction, he is speaking the truth. ${ }^{54}$ Attempting to refute him, Polus introduces the example of the alleged happiness of Archelaus, tyrant of Macedonia, who perpetrates many injustices, doing what seems best to him. When Polus suggests that Socrates would probably also claim not to know if the Great King of Persia is happy, Socrates responds, saying: "And I would be saying the truth [Kàे $\dot{\alpha} \lambda \eta \theta \tilde{\eta} \gamma \varepsilon \dot{\varepsilon} \rho \tilde{\omega}]$, for I do not know how he is

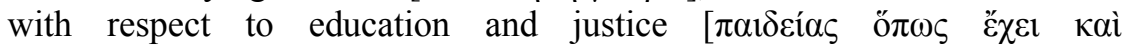

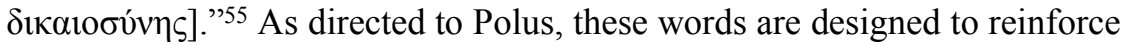
Socrates' claim to truth and undermine Polus's suggestion earlier that even a child could refute the truth of the things Socrates says. They also make the question of happiness one of education and justice, both of which turn out to be central to Socrates' understanding of the political art as a practice of speaking the truth.

The politics of truth is not simply a matter of speaking toward the best, but is also concerned with moving the determinate individual with whom it is engaged in dialogue to consider the question of justice. Thus, in his discussion with Polus, Socrates claims truth as his birthright, insisting that it requires the witness not of many but of one. ${ }^{56} \mathrm{He}$ puts it this way: "If I do

${ }^{54}$ Socrates insists that he speaks the truth at Gorg. $468 \mathrm{c} 7-8$ and $468 \mathrm{e} 3$, Polus contests it at $470 \mathrm{c} 4-5$.

55 Gorg. 470e6-7. If we attend to the way Plato writes what Socrates says here, we gain

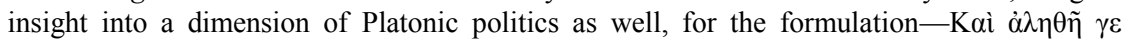
$\dot{\varepsilon} \rho \tilde{\omega}-$ is morphologically ambiguous. The word $\dot{\varepsilon} \rho \tilde{\omega}$ can be read, as it is translated here, as the first person present subjunctive active of eipé $\omega$, which means 'to say.' But morphologically, $\dot{\varepsilon} \rho \tilde{\omega}$ can also be the first person subjunctive present of ' $\dot{\varepsilon} \rho \alpha \omega \omega$,' which means 'to love,' thus making the phrase read: "And I would be loving the truth." While this would be a plausible translation of the phrase even in this context, the formulation as written could be read in yet a more striking way; for if we take $\dot{\varepsilon} \rho \tilde{\omega}$ as a second person singular present imperative middlepassive of $\dot{\varepsilon} \rho \alpha ́ \omega$, we would need to hear it as enjoining the individual reader to: "Love truth!" Such a translation would not fit well into the present context, but what shows itself in the writing - namely, the injunction to love truth and to understand this love as bound up with the question of a good education and a concern for justice- says something decisive the politics of Platonic writing. If Socrates uses words to move Polus to a deeper understanding of the power of words rooted in a concern for justice, Plato writes in such a way to move us similarly.

${ }^{56}$ Gorg. 472b4-c1. Indeed, Socrates enjoins: "don't try to separate me from my very be-

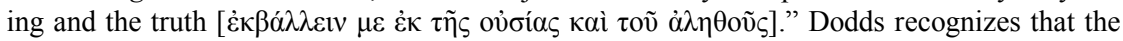

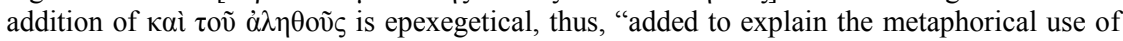
$\tau \tilde{\eta} \varsigma$ ov̉oías." While he is likely correct to suggest that this term is to be taken in the sense of one's material inheritance, its meaning remains saturated with the more philosophical sense of "substance, or being." Thus, Dodds underestimates what is at stake in the Gorgias when he 
not bring you yourself forward as one witness to agree with the things concerning which I speak, I think that I have accomplished nothing worth

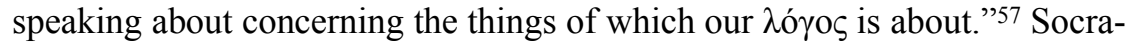
tes reinforces this a moment later when he claims not to be a politician in the traditional sense precisely because he only knows how to bring forth a witness of one, namely, as he says: "the very one toward whom there is a $\lambda$ óyos for me." 58 By formulating it this way, Socrates emphasizes that the $\lambda$ ó $\gamma$ os exists for him as directed toward the one with whom he speaks. Thus, the politics of truth speaks in two directions. It speaks at once toward the best and yet also toward the one with whom it is engaged. To do this well, however, as Socrates does, one must remain attuned always at once to the question of the best and to the determinate individual with whom one is speaking. Thus, in attempting to turn Polus toward the just, Socrates appeals to provocative examples that challenge the way Polus understands the nature of power. First, in order to uncover the truth that force is not power, Socrates offers the example of a dagger brandished in the crowded market-

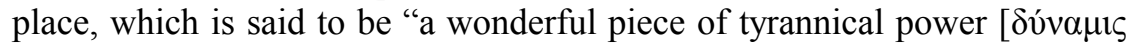

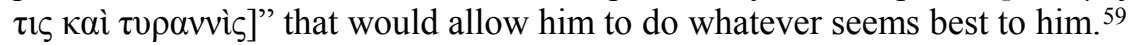
Second, however, Socrates provocatively turns the values Polus embraces on their head, advocating that if we truly want to harm our enemies, we should contrive a way for them to escape and not pay a just penalty. ${ }^{60}$ Although the things Socrates says here are directed toward Polus, and toward the best, they are, as we have heard, more effective in moving Callicles into the dialogue than they are in moving Polus to consider more deeply how his own words relate or fail to relate to the best. Nevertheless, a deeper understanding of the relationship between truth and power has been gained in dialogue with Polus, for power is now understood to be rooted in an ability to speak truth both toward the best and toward the one with whom one is engaged.

insists: "Polus might rob Socrates of a true opinion, but could hardly rob him of his substantial existence." See Dodds 1959, 245. That Socrates' substantial existence is at stake is made clear by the appeal, in the present context, to what the many Athenians will think if he brings witnesses against him (472a2-5) and, in the discussion with Callicles, when the possible trial and execution of Socrates is explicitly evoked (486a7-d1; 521b4-d4).

57 Gorg. 472b6-c1.

58 Gorg. 474a6.

${ }^{59}$ Gorg. $469 \mathrm{~d} 1-\mathrm{e} 8$. Jaeger is right to insist that Socrates takes the notion of power as the ability to do what one wants and transforms it. See Jaeger 1943, 134. If the idea of power Polus embraces may be called force, then Socrates might be said to advocate for a conception of power as the ability, cultivated by good education and a concern for justice, to use words to turn the community toward the best.

${ }^{60}$ Gorg. 480e5-b5. 


\section{Callicles: Attempting a True Politics}

Moved by these Socratic provocations, Callicles attacks Socrates as a "true demagogue" who, while "claiming to pursue truth," in fact engages in "disgusting demagoguery." ${ }^{61}$ Again, the dialogue is animated by the contested question of truth, which here leads Callicles to accuse Socrates of deceptively playing with the distinction between nature and law, pv́oıs and vó $\mu$ os, "working wickedness with words," as he puts it. ${ }^{62}$ With these words, Callicles has indeed touched the root of the Socratic practice of politics, for in attempting to move people by speaking truth, Socrates does not respect the manner in which Callicles understands the relationship between pú and vó $\mu \varsigma^{63}{ }^{63}$ For Callicles, the use of force is by nature just; it is, indeed, the very "law of nature, though perhaps not in accord with the one we ourselves make." ${ }^{\prime 64}$ For Socrates, as we have heard, true power is not a matter of moving others by force, but an ability to speak toward the best. Thus, although Socrates never explicitly inverts Callicles' bold formulation about the "law of nature," his suggestion that is it not only by convention that doing injustice is more shameful than suffering it, but also by nature, implies that it might be necessary to think more deeply about the nature of law. Indeed, Socrates claims that Callicles is likely not to have been speaking the

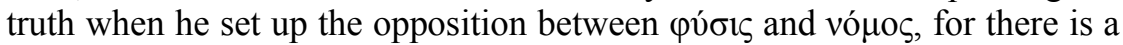
sense in which vónos itself grows out of a natural attempt to articulate the truth of things. ${ }^{65}$ But it is not that human conventions simply express the nature of things straightaway; rather, they are rooted in an originary experience with things that is capable of moving humans together in healthy ways if the words we speak to and with one another are animated by a concern to

61 Gorg. 482a5, 482c5 and e3-5.

${ }^{62}$ Gorg. 483a2-3.

${ }^{63}$ Saxonhouse recognizes that Socrates does shift back and forth between $\varphi v ́ \sigma \varsigma \varsigma$ and vó $\mu$ os, pointing to 474c and 478a, b and d. See Saxonhouse 1983, 147-48. She recognizes that Callicles is attempting to "unite the two concepts in a startling new phrase 'the law of nature' (nomos tes physeos, 483e), a law of inequality supported by nature herself, as seen among animals and most significantly among nations where the question of right (dike) is only spo-

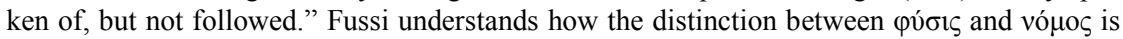
used in the dialogue to give rise to the opposition between philosophy and politics. See Fussi, 1996, 119. As we will hear, however, Socrates attempts to blur the difference because he wants to root politics in philosophy. Jaeger ascribes to Plato a position we hear Socrates seeking to establish in his discussion with Callicles: Plato "did not think of nature (as the sophistic teachers did) as raw material out of which education was to form a work of art; he thought it was the highest areté, which is only incompletely manifested in individual man." See Jaeger 1943, 134.

64 Gorg. 483e1-4.

${ }^{65}$ Gorg. 489a8-b6. 
uncover the truth. Callicles himself lays claim to a different truth: that excellence and happiness are "luxury, licentiousness, and freedom, if [each] is held with mercenary force." $" 66$ All conventions contrary to this natural law of force are, according to Callicles, worthless. And even when Socrates leads Callicles through the implications of this alleged "truth"-a journey that ends at the life of a catamite-Callicles cannot proceed, for he shows himself to have no relationship with the truth, no ability to be moved by anything other than a desire for gratification and no ideal toward which his words might be held accountable. ${ }^{67}$

In order to hold this account itself accountable to something beyond mere gratification, Socrates directs Callicles to attend to "that concerning which these $\lambda$ ó $\gamma$ or exist for us," which he identifies as "the way it is necessary for one to live, whether it be the life to which you call me, doing the things of a real man, speaking to the populace and training in rhetoric and being political in the way you people engage in politics nowadays, or if it is this life in philosophy, and whatever it is about this life that differs from that." 68 To delineate this life from that, Socrates returns to the analogy between the care of the soul and the care of the body he had established with Gorgias in the discussion with Polus. ${ }^{69}$ In so doing, Socrates lends further determination to the meaning of his own $\pi$ o $\lambda \iota \tau \iota \kappa \eta ~ \tau \varepsilon \dot{\varepsilon} \chi \nu$. The difference between the practice of popular politics and the life of philosophy is articulated in terms of the difference between the knack for cooking tasty foods and the art of doctoring. Here again Socrates emphasizes that doctoring is an art precisely because it "looks to the nature of the one upon whom it attends, acts from what is responsible and has a $\lambda$ ó $\gamma$ os to give about these things." 70 Socrates goes on to suggest that there is a similar art concerning the soul, which "also has some forethought $[\pi \rho \rho \mu \eta \theta \varepsilon \varepsilon \alpha]$ concerning what is best for the

\footnotetext{
66 Gorg. 492c3-6.

${ }^{67}$ For the catamite, see, Gorg. 494e4. Callicles himself insists that his continuing in discussion with Socrates is due simply to a desire "to gratify Gorgias here" (501c7-8). Buzzetti claims that Callicles does not have the ability to recognize that justice places demands upon us. See Buzzetti 2005, 26-7. Tarnopolsky argues that it is ultimately the catamite example that succeeds in shaming Callicles. See Tarnopolsky 2010, 81. Teloh calls it a "shocking attempt at coercive persuasion" (Teloh 2007, 68). As we have suggested, Socrates had managed to move Callicles to engage him in discussion by provoking Polus. Here, however, Callicles shows himself capable of moving only so far. He is provoked to speak by the desire to shame Socrates, and, presumably, the pleasure he believed he himself would gain in the process. Now, when he is invited to allow the desire for truth to orient his engagement with others, he becomes recalcitrant.

68 Gorg. 500c1-8.

${ }^{69}$ See, Gorg. 464b2-466a3, and p. 166 above.

${ }^{70}$ Gorg. 501a1-3.
} 
soul." 71 Thus, in wrapping the political activity he claims to practice in the mantle of a $\tau \dot{\varepsilon} \chi \vee \eta$, Socrates seems to embrace three abilities at once: first, the ability to look into the nature of the one with whom one is engaged; second, the ability to act rooted in an understanding of what is responsible for the present condition of the one for whom one cares; and third, the ability to thoughtfully anticipate what is best for the soul of the one for whom one is concerned. These three abilities are intimately bound up with the

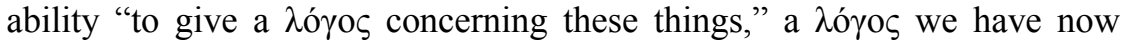
heard to be rooted in the attempt to speak truth with an eye toward justice. This way of speaking might, indeed, be called a certain kind of rhetoric, and Socrates goes so far as to say that such a rhetoric would be "a beautiful thing, preparing the souls of the citizens such that they will be the best possible, and striving earnestly to say the best things, whether they are pleasing or more unpleasant to those listening." 72 These words lend depth and determination to Socrates' articulation of his own political practice as a $\tau \dot{\varepsilon} \chi v \eta$. Indeed, Socrates has been practicing this $\tau \dot{\varepsilon} \chi v \eta$ with Gorgias, Polus, and Callicles all along; for the things Socrates says demonstrate that he has discerned the nature of the soul of each, that he understands what is responsible for their present conditions, and that he has an anticipatory understanding of what is best for them.

The analogy with the art of doctoring that runs through and connects Socrates' discussion with his three listeners in the Gorgias, further enriches the manner in which Socratic politics must be understood as an art of speaking. Appealing to the way the word "healthy" points to the ordered arrangement of the body from which "health" comes to be present in bodies, Socrates suggests that there is a certain "law," or vó $\mu \mathrm{o}$, an ordered arrangement of the soul from which the soul too becomes, "law-abiding," vó $\mu$ нov- that is, healthy. Justice and temperance are two such laws. ${ }^{73}$ The return to the question of the law here suggests the degree to which the law itself is rooted in the natural operations of the soul. Socrates implies by this a reversal of Callicles' "law of nature," suggesting that the nature of law is to ensure the healthy life of the community. This is brought about, however, only by ways of speaking that are "artful and good." The one who practices the beautiful rhetoric of philosophical politics, then, will be one who looks toward justice and temperance, as the doctor looks toward the healthy order-

71 Gorg. 501b2-5.

72 Gorg. 503a7-9. Just prior to this, Socrates had spoken of this beautiful rhetoric as "always speaking towards the best," a formulation that echoes the things Socrates said about politics as the care of the soul at $464 \mathrm{c} 4$ and anticipates the formulation by which he articulates his own political art as a ways of speaking towards the best at $521 \mathrm{~d} 6-\mathrm{e} 2$.

${ }^{73}$ Gorg. 504c7-d3. 
ings of the body, and as Socrates emphasizes, he "will bring them to bear on our souls in speaking speeches and in all actions." "Th This articulates well what it means to "attempt the political art truly," which Socrates claims is the way he is one of few now living who does political things. Politics is thus heard to be rooted in philosophy.

\section{The Poetics of Platonic Politics}

If, however, the practice of Socratic politics involves, as we have heard, speaking and thus acting in ways that are attuned to the concrete individual and directed toward justice and the best, we are now in a position to recognize how Platonic writing performs a similar political practice with us. The text has been crafted in such a way that each of us is led to consider the health of our souls and the course of our own lives. The path of truth that runs like Ariadne's thread through the Gorgias has led us to this recognition and stands as an example of the poetics of Platonic politics. It is Gorgias who first enunciates "truth" in the dialogue, and as he is led to recognize the political power endemic to the attempt to speak truth with an eye toward justice, we are made to feel the power of words to do political things. The loyalty to the $\lambda$ ó ${ }^{\circ}$ s Socrates is able to cultivate in Gorgias appears in the discussion with Polus when the true difference between a $\tau \dot{\varepsilon} \chi v \eta$ and an experience is established, and we are made aware of a central difference be-

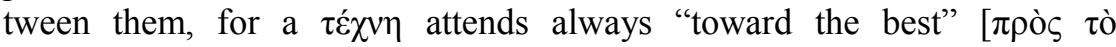

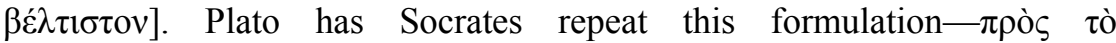
$\beta \varepsilon \dot{\lambda} \tau \imath \sigma \tau o v$ - when he articulates the beautiful rhetoric, artful and good, that is able to move others by words to consider the health of their souls. That someone in the dialogue has been so moved, is evident when Gorgias speaks up to save the $\lambda$ ó $\gamma$ o $\varsigma$ between Socrates and Callicles from a premature end. Gorgias's words testify to the power of Socratic politics, for he

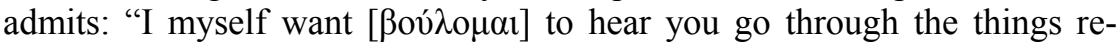
maining yourself." 75 The desire he expresses here is rooted in a concern for a $\lambda$ ó $\gamma$ o 5 articulated toward the best and thus stands in tension with what might seem best for Gorgias, given his own interest in procuring students. Yet, by making these the last words Gorgias speaks in the dialogue, Plato invites us to consider how they empower Socrates to continue along a road that leads not only to the articulation of a practice of politics determined as the art of speaking the truth, but also ultimately to a myth that is said to be a

\footnotetext{
74 Gorg. 504d6-8.

${ }^{75}$ Gorg. 506b2-3.
} 
$\lambda$ ófo 5 precisely because it is spoken as true. Socrates puts it this way: "Listen to a quite beautiful $\lambda$ ó $\gamma \circ \varsigma$, as they say, which you will consider a myth, but I, indeed, think it is a $\lambda$ ó $\gamma o s$, for I will be saying the things I am about to say as true." ${ }^{\prime 6}$ The details of the story in which we are judged naked in body and soul, by naked judges who are able to see us for what we have done and thus for who we are, is indeed beautiful. But the truth of it lies in the way the story enjoins each of us who encounter it to consider the degree to which we ourselves are living a healthy life in body and soul, a life that Socrates describes at the end of the dialogue as an attempt. Of his life, of the practice of his philosophy, and so also of his attempt to do political things, Socrates says, "I will try, by practicing truth, to live by being the best I can possibly be, and, when I die, to die that way too." 77 Crafted by Plato, these words, like all the words in the dialogue, put truth into practice by attempting to speak toward the best, and seeking in so speaking to turn us, you and me, toward the question of justice as that erotic ideal that opens the possibility of true human political community.

PENNSYLVANIA STATE UNIVERSITY

76 Gorg. 523a1-3.

77 Gorg. 526d5-e1. 


\title{
COMMENTARY ON LONG
}

\author{
NALIN RANASINGHE
}

\begin{abstract}
Long finds that Socrates' sincere commitment to dialogue and joint seeking after truth disarms his belligerent interlocutors, brings them under the authority of the logos, and gives self-knowledge along with a newfound sense of the common good. He says that the true political art can "look into the soul, understand its condition and see what's good for it." My commentary challenges his assumption that Socrates and Gorgias become friends and suggests that the nature of the soul dictates that this political art's effects are more negative than positive. But I agree with Long's emphasis on the non-adversarial nature of dialogic speech and urge him to elaborate on its ontological basis: a cosmos held together by partnership and friendship between gods and men.
\end{abstract}

I will first praise Professor Long for his choice, and non-disingenuous reading, of this dialogue. Despite being the third longest and perhaps the clearest of Plato's works, the Gorgias has long been neglected by many Plato scholars. Philosophers have often preferred the Republic to the Gorgias, perhaps because we don't like to be preached at. As Epictetus would have observed, we prefer discussing the meaning of virtue or even studying the origins of the imperative to live virtuously to actually living virtuously. ${ }^{1}$ This is why we prefer the grotesque caricature of Socrates as bumbling buffoon, kindly offered by Aristophanes in the Clouds, and avoid dealing with the stern prophet of the Gorgias. Indeed, consciously or not, many scholars like to use the Clouds as a kind of vaccination against the sternness of the Apology; following the advice of Gorgias himself, they would use the comedy of the Clouds to deflate the angry accusations of the Apology.

Put differently, the Republic appeals to the mad-scientist and utopian dreamer that lurks within every absent-minded professor. We're much happier discussing an outlandishly utopian work that seems to require the readily assessed traits of philological precision and technical cleverness. Perhaps we all believe that philosophy cannot help souls or cities to live virtuously? Regardless of whether this impotence is caused by original sin or consumerism, most of its teachers believe that philosophy is a childish pursuit only good for getting high GRE's and admission to law school. Callicles would be proud of us!

\footnotetext{
${ }^{1}$ See Epictetus, Enchiridion chapter 52 in Discourses and Selected Writings, trans. Robert Dobbins (Penguin Classics, 2008), 244-45.
} 
The Gorgias is important because it states positively what the Republic only indicated indirectly by the typical Platonic device of a reductio ad absurdum. ${ }^{2}$ Unlike the Republic, which describes a totalitarian regime so beautiful to the ambitious that Socrates' pedagogic irony is ignored, thus rendering him young and beautiful, Long sees that the Gorgias unmistakably defends the possibility of personal integrity and virtuous political art: the basis of a moral soul and a just city. This makes Socrates more erotic to the soul and uglier to the body and mind to the extent that he makes stern moral demands of us.

Professor Long claims that the practice of Socratic philosophy has great transformative power. This is shown by the "burst of thumotic energy" evoked by Socrates' erotic art that forces Callicles to reveal his nihilistic world-view to Gorgias - his intellectual grandfather. Professor Long discovers this insight into Callicles' worldview at the very center of our dialogue. We find that Callicles too, like many of Socrates' victims or interlocutors, is numbered among the prophets; he is involuntarily compelled by the art of Socrates to see and proclaim that his life follows a course directly contrary to that pursued by Socratic political philosophy. Further, Long suggests that Callicles' outburst is prompted by Socrates' assertion that "an unjust deed must not be hidden but instead brought into the open so as to be punished and made healthy" (480c). Contrary to the maxims of esoteric political thought and expensive sophistic education, Socrates' maieutic art succeeds in revealing the nihilistic view of reality ruling Callicles' soul. As Gorgias advised, this tragic impulse must be exposed to comic ridicule and shame so it may self-destruct. Socrates had hitherto done this privately "whispering in corners" (485e), now Callicles himself demands that his punishment take place in public.

And so Callicles' moment of self-clarity precedes his justly or unjustly frequently anthologized speech where he threatens Socrates with bodily violence after denouncing Socratic philosophy for being ridiculous and unmanly (485a-d). Before doing so, he was unsettled enough to observe that if Socrates is correct, life as it is currently lived would be turned upside down (481c). In other words, Callicles' speech and deeds are quite consistent; his angry words are uttered in defense of a view of reality itself as chaotic, ruled by violence and defended by thumotic love of one's own; his consciousness is as strife ridden as the external reality he inhabits. In his eyes the Peloponnesian War has revealed that the gods are dead or non-existent,

${ }^{2}$ See Ranasinghe, The Soul of Socrates (Cornell University Press, 2000) 1-27. 
and that evil goes unpunished. ${ }^{3}$ In such a reality glory and pleasure are fleeting; the only pure happiness is gained by acts of destruction and selfdestruction. This is the 'cash value' of the victory-driven life.

In this seeming chaos, Gorgias' notorious tripartite account of Nature holds: nothing exists; and if it anything exists it is unknowable; and if it exists and is knowable, yet it cannot be indicated to others. ${ }^{4}$ As this chaos is either god-forsaken, or entirely materialistic, man's natural need for meaning is catered to by myth-making rhetoricians. This is why Gorgias says that his art brings freedom to its user as well as rule over his city (452d). So that sheep may safely graze, and artisans may go about their daily business unimpeded, this artificial political theology is guarded by angry warriors. This tripartite structure has more than a passing resemblance to Plato's Republic; Gorgias' agnosticism seems to make him a Socratic doppelgänger! Once again, the Gorgias and Republic seem to provide sharply differing takes on reality.

If Callicles has correctly described reality, then the Socrates of the Gorgias is either a demagogic knave or an even greater fool in the cave of the Republic. In any case we surely do not seem to take his words seriously today. Socrates' belief in the possibility of a cosmic order sustaining a temperate life has been rejected both by religious right and the scientific left: the right condemning him for his Pelagian optimism/ignorance of original sin, for else Christ died in vain, and the left ridiculing his antiquated belief in such things as virtue, the soul, and the cosmos. For better or worse we too live in a world dominated by religious strife and technological violence. Man can either humbly submit to God's inscrutable plan or enslave reason to serve his own insatiable passions. Likewise Callicles-whose name means 'called beautiful' or 'he called me beautiful all night long' — greatly resembles a typical disenchanted youth who has been pandered or marketed to from infancy; born and bred in conditions of strife nothing else is known to him beyond its violent necessity. His sense of what is real is warped by the endless pursuit of pleasure and power. Thus victory matters more to him than truth since the latter doesn't exist independently of power relations; likewise, self-forgetting pleasure replaces the belief in long-term happiness or a good life. This stance alienates him from self-knowledge and any sense of abiding reality. He is incorrigibly ignorant. Surely he cannot share in a sincere conversation with Socrates about what is best? Isn't Socrates simply

\footnotetext{
${ }^{3}$ See Thucydides, Peloponnesian War 3.82-84. This is why Thucydides calls the Peloponnesian War the "greatest movement yet known in history"; it overthrew the previous, Homeric, dispensation of a world order ruled by anthropomorphic gods.

${ }^{4}$ Pseudo-Aristotle, Melissus, Xenophanes and Gorgias, 979a10.
} 
shaming Gorgias by showing this itinerant drug dealer the long-term results of his wares?

Beyond forcing us to ponder the extent to which we can be led to mutilate the windows of our soul, and visually imprison ourselves in a Hellish underworld of our own making, Professor Long also challenges us to rethink our view of the power of Socratic medicine. The Socratic political art, as he describes it, is as relevant to our time as it was to the terrible years after the Peloponnesian War. He claims that dialogic speech, directed towards truth rather than victory, and the good of all as opposed to adversarial agon, persuades us to recognize the authority of truth and the reality of the common good. Long suggests that Socrates' sincere commitment to dialogue and the joint seeking after truth disarms his otherwise belligerent interlocutors, brings them under the authority of the logos, and gives them selfknowledge along with a newfound sense of the common good. Even as two of them denounced Socrates' use of shame to make his point, all three of his interlocutors were made to testify against rhetoric under the influence of this logos. I am curious about what Professor Long can say about the origin of this revelatory power. I certainly applaud his emphasis on joint essaying - epicheirein - rather than creation.

Clearly this concern for the 'common good' or 'what is best' is marked by the spirit of honest inquiry and sincerity guiding all parties amidst uncertainty and contingency, rather than a victory-driven desire of a selfprofessed expert to implement his agenda. This suggests that this common good is as least as much a spirit or disposition as it is a definite result or product. Since Socrates has the utmost contempt for statesmen who built many magnificent edifices, whitened sepulchers, whilst corrupting the body politic (519a) we can conclude that this 'true political art' is based on individual integrity and public friendship. But can these qualities be nurtured in a way that refutes Mark Antony's insight that while "the evil that men do lives after them, the good is oft interred with their bones"? ${ }^{5}$ Can we go beyond refuting ignorance and exposing vice? What does the true political art create? Should we not beware of trying to fashion souls, cities, or images of the cosmos as if they could ever be finished objects or products of our art? Doesn't their reality belong more to the realm of epicheirein and Aletheia?

In other words, inquiring before and beyond this spirit of honesty and public spiritedness we surely cannot avoid questions concerning human nature and the ultimate character of reality itself. As Long subtly implies, Socrates suggests that our preoccupation with strife and adversarial interaction is blameworthy and deleterious because it both stifles the soul's capaci-

${ }^{5}$ Shakespeare, Julius Caesar, III. ii 72-73. 
ty for temperance and diminishes its ability to interact with a subtly benevolent cosmos. This conviction also surely sustains Socrates' belief in a true art of rehabilitative justice for the diseased soul that complements the true political art and its positive celebration of a good life. Yet it seems that the Gorgias itself, like any other Socratic text, functions more at the level of justice than politics. In other words, we almost invariably see Socrates engaged in the task of punishing and healing ignorance, stripping away false knowledge and adversarial attitudes; we do not see him engaged in the characteristic political task of deliberating about what is good for the city in the company of other similarly disposed virtuous citizens. Surely this suggests that the true political art is negative rather than positive? Socrates' daimon, however we view it, also serves in a like capacity-only warning us of our limits and of what must not be ventured, rather than inspiring us to do positive deeds. How much positive transformative power does this political art have? Is there good rhetoric? Is it irresistibly transformative?

My qualified skepticism here also extends to Professor Long's claim that Socrates and Gorgias have become friends; my take on the matter is that their objective enmity will persist unless Gorgias renounces his trade. Physicians and drug-dealers cannot be friends. While there are many Platonic political philosophers who favor an alliance between Socrates and Gorgias, these parties also reject notions of the common good and hold that noble lies and political theologies are all part of a philosopher's stock in trade. These gentlemen are generally very suspicious of Socrates and tend to read him on horseback whilst facing the East. Surely Long does not share their esoteric views? It is more likely that Socrates punishes Gorgias by forcing him to gaze on the diseased souls of his students and victims. Long reminded us of Aristotle's words, "it is not possible or easy to change by words things that from long ago have taken hold in people's character" (EN X 9, 1197b). Perhaps the political art can do little more than force us to observe the causes and effects of our corruption. How this knowledge is used is ultimately up to the patient's will. The souls' transformative powers can lead it to see white as black or vice versa.

Let us now pay further attention to the question of the soul. While I agree fully with his treating the soul as the basic building block of Socratic philosophy, Professor Long claims that the political art is able to look into the soul, understand its condition, and even see what's best for it. Although we see how the power of the logos makes it often possible for Socrates to make a soul reveal its disease - disguised as wisdom - and perhaps even disgorge it, it is surely much harder to see the soul of another-or even to make him see his own soul. By the time a soul's interior is writ large on a face or life, it is all but irreversible: one is either a saint or a monster. Does Long be- 
lieve that any practitioner of this art can look into any soul and tell what's good for it?

My own view is that Socrates is well aware of the soul's terrible powers of autonomy and inviolability. This is why he relies on myth and indirect suggestion. Again, a misplaced emphasis on verbal victory can occur at the cost of true learning, which always requires humility on the part of the teacher/midwife along with the co-operation of the student, and often occurs in retrospect. The Platonic texts seem to suggest that even the gods cannot violate the freedom of the will. This is why Socrates says that even gods and men are held together by friendship in a cosmos of geometric equality and right proportion (508a). Professor Long certainly agrees with me to the extent that he speaks of the law and ordered arrangement of the soul by which it becomes healthy, but I wonder if he agrees with Socrates' statement about the cosmos? In other words, what sort of ultimate reality does this true political art presuppose and uncover? Are we, as philosophers, obliged to deny the possibility of any overarching wisdom - however subtle - and blindly assert that human life, and indeed all reality, are as Hobbes described them?

I will conclude by claiming that a fine and enduring image of true political art is found in the myth at the end of the Gorgias - though it's strangely called a true logos by Socrates (523a). Here we see a reversal of Hades: instead of the dead having 'no-idea' of their former life, for the first time the irreversible damage that evil has inflicted on their souls is visible to all. This damage or self-mutilation is its own penalty. They simply must live with full self-knowledge. This is quite consistent with the infinite labors of the literally dis-eased souls in Homeric Tartarus. Since Socrates, who prided himself on his ignorance of things under the earth, says this is a true account, he seems to be describing his this-worldly activity of revealing to the living the damage that that they have inflicted on themselves while there is still time for rehabilitation. At the very least others, ourselves included, may profit from these 'rare examples' of the eternal law: evil carries its own penalty. We're not cosmic orphans left to our own vices or technical devices by uncaring gods. All is not permitted. 


\section{LONG / RANASINGHE BIBLIOGRAPHY}

Arieti, J., and R. Barrus. 2007. Plato's Gorgias. Newburyport: Focus Publishing.

Brickhouse, T., and N. Smith. 2002. The Trial and Execution of Socrates. New York: Oxford University Press.

Burnet, J. 1900-07. Platonis Opera. 5 Vols. Oxford: Oxford University Press.

Buzzetti, E. 2005. The Injustice of Callicles and the Limits of Socrates' Ability to Educate a Young Politician. Ancient Philosophy 25:25-48.

Dobbins, R. 2008, tr. Epictetus: Discourses and Selected Writings.

Dodds, E. R. 1959. Plato Gorgias: A Revised Text with Introduction and Commentary. Oxford: Oxford University Press

Fussi, A. 1996. Callicles' Examples of nomos tes phuseos in Plato's Gorgias. Graduate Faculty Philosophy Journal 19:119-149.

- 2001. Socrates' Refutation of Gorgias. In Proceedings of the Boston Area Colloquium in Ancient Philosophy 17, eds. J. J. Cleary and G. Gurtler, 123-145. Leiden: Brill.

Gould, J. 1972. The Development of Plato's Ethics. New York: Russell and Russell.

Irwin, T. 1979. Plato's Gorgias. Oxford: Clarendon Press. . 1979. Plato's Moral Theory: The Early and Middle Dialogues. Oxford: Oxford University Press.

Jaeger, W. 1943. Paideia: The Ideals of Greek Culture. New York: Oxford University Press.

Kahn, C. H. 1983. Drama and Dialectic in Plato's Gorgias. In Oxford Studies in Ancient Philosophy 1:75-121.

Kastely, J. L. 1991. In Defense of Plato's Gorgias. PMLA 106:96-109.

Liddell, G. H., and R. Scott. 1968. A Greek-English Lexicon, $9^{\text {th }}$ Edition. Oxford: Oxford University Press.

Long, C. P. 2011. Aristotle on the Nature of Truth. Cambridge: Cambridge University Press.

- 2011. Crisis of Community. Epoché 15:361-377.

Lyons, J. 1963. Structural Semantics. Cambridge: Cambridge University Press.

McKim, R. 1988. Shame and Truth in Plato's Gorgias. In Platonic Writings, Platonic Readings, ed. C. Griswold, 34-48. New York: Routledge.

Monoson, S. S. 2000. Plato's Democratic Entanglements. Princeton: Princeton University Press.

Nails, D. 2002. The People of Plato. Indianapolis: Hackett Publishing.

Nussbaum, M. C. 1986. The Fragility of Goodness. Cambridge: Cambridge University Press.

Pickard-Cambridge, A. W. 1933. Tragedy. In New Chapters in the History of Greek Literature, ed. Powell, 68-155. Oxford: Clarendon Press.

Ranasinghe, N. 2009. Socrates in the Underworld. South Bend: St. Augustine's Press. 2000. The Soul of Socrates. Ithaca: Cornell University Press.

Rocco, C. 1996. Liberating Discourse. Interpretation 23:361-385.

Roochnik, D. 1996. Of Art and Wisdom. University Park: Pennsylvania State University Press.

Saxonhouse, A. W. 1983. An Unspoken Theme in Plato's Gorgias. Interpretation 11:139-69. 
2006. Free Speech and Democracy in Ancient Athens. New York: Cambridge University Press.

Stauffer, D. 2006. The Unity of Plato's Gorgias. Cambridge: Cambridge University Press.

Tarnopolsky, C. H. 2010. Prudes, Perverts, and Tyrants. Princeton: Princeton University Press.

Teloh, H. 2007. Rhetoric, Refutation, and What Socrates Believes in Plato's Gorgias. In Proceedings of the Boston Area Colloquium in Ancient Philosophy 23, 57-77.

Wecklein, N. 1924. Die Antiope des Euripides. Philologus 79:51-69.

Weiss, R. 2003. Oh, Brother! The Fraternity of Rhetoric and Philosophy in Plato's Gorgias. Interpretation 30:195-206. 